for the banana industry. Rice production is being developed. In British Guiana a series of drainage schemes are starting which it is hoped will revolutionize rice growing. The most important thing, however, is to attack illiteracy. The growing political consciousness of the Colonial peoples must be developed on sound lines, but the diversity of conditions in the Colonies makes a standardized approach inapplicable. Continuous association of Colonial peoples with their own welfare and development, and cooperation of all concerned, from the highest to the humblest official, in this endeavour, are the methods to be used. Sir Edward Grigg's amendment was then withdrawn.

\section{International Copyright}

Mr. G. Wren Howard and Mr. Stanley Unwin, both of whom are past presidents of the Publishers Association of Great Britain, have issued a statement raising the thorny issue of international copyright. They point out that the last International Copyright Convention, signed at Berne in 1908, afforded a very considerable degree of protection to the literary and artistic property belonging to the nationals of those countries which signed it. The position to-day, however, is that, of the major active members of the United Nations, the British Empire alone is adherent to the Berne Convention. While Germany, Italy and Japan signed it, the United States of America, the U.S.S.R., and the Chinese Republic did not do so. For practical purposes, almost complete protection is enjoyed by the literary property of United States citizens throughout the British Empire, but it is difficult, owing to the conditions imposed, for British subjects to obtain copyright for their property in the United States. Again, while a translation from the Russian into English is copyright in Great Britain and throughout the Empire, no copyright is afforded to any British literary material by the U.S.S.R.; in China, a considerable trade in material reproduced by photographic process has grown up. It is therefore urged that steps should be taken forthwith, as a part of the plans for reconstruction which are under discussion, to introduce a system of international copyright as soon as world conditions permit.

\section{Exhibition of Newton's Books}

As exhibition of books connected with Newton is being held in the Wigan Central Library from November 23 until early in 1943, to celebrate the tercentenary of the birth of Sir Isaac Newton, at Woolsthorpe, Lincolnshire, on Christmas Day 1642. The exhibition was conceived and organized by the borough librarian, Mr. Arthur J. Hawkes. He has managed to bring together from the resources of the Wigan Library, supplemented by a few books on loan, a most interesting collection of early works on science. It includes copies of most of Newton's published scientific papers and books, together with about one hundred works of earlier and contemporary authors bearing on Newton's discoveries. The original issues of the Philosophical Transactions of the Royal Society in the possession of the Wigan Library are exhibited, together with the first editions of Newton's "Opticks" (1704), loaned by Messrs. Bernard Quaritch, Ltd., and the " $\mathrm{De}$ Revolutionibus Orbium Coelestium" by Copernicus (1543), loaned by the Earl of Crawford. Messrs. Sotheran, Ltd., have loaned the copy of Isaac Barrow's edition of Euclid which was used by Newton as a student at Trinity
College and bears many annotations in Newton's handwriting. All the books exhibited carry lengthy notes attached to them explaining their interest and significance in connexion with Newton.

The exhibition was opened on November 23 by Mr. Leonard Stanley Newton, who is a descendant of the Woolsthorpe family. Wigan is to be congratulated on not letting pass, in war-time, the occasion to celebrate the three hundredth birthday of Newton by the exhibition of "so many and valuable philosophical truths as were never yet discovered and put beyond dispute by the capacity and industry of any one man whatever".

\section{Ministry of Health: Medical Advisory Committee}

The Parliamentary Secretary to the Ministry of Health stated in the House of Commons on November 28 that a Medical Advisory Committee has been set up to advise the Minister on the medical aspects of problems relating to the health of the people. The members of the Committee are :

The presidents of the Royal College of Physicians, the Royal College of Surgeons, and the Royal College of Obstetricians and Gynaecologists ; the chajrman of Council of the British Medical Association; Dr. G. C. Anderson; Dr. J. C. Arthur; Miss A. Bloomfield ; Dr. J. A. Brown ; Dr. E. Rock Carling ; Dr. J. A. Charles; Prof. H. Cohen; Dr. W. Allen Daley; Lord Dawson of Penn; Dr. E. A. Gregg ; Lord Horder ; Sir Wilson Jameson (vice-chairman); Dr. W. S. Macdonald; Dr. A. A. Moncrieff ; Prof. R. M. F. Picken ; Prof. H. Platt ; Dr. A. T. Rogers; Dr. D. O. Twining; Dr. O. Williams; and Miss A. L. Winner.

\section{Imperial Institute of Entomology}

SIR GUY Marshall retired recently from the post of Director of the Institute and has been succeeded by Dr. S. A. Neave. The work of the Institute is well known. It publishes the Review of Applied Entomology and the Bulletin of Entomological Research, identifies insects submitted by entomologists from all parts of the world, distributes collections of named insects, provides initial stocks of parasites of economic importance, and acts generally in an advisory capacity and as a clearing house for matters connected with applied entomology throughout the Empire. A vacancy on the staff has just been filled, but there will be two others within the reasonably near future, and suitable candidates for these posts are now being sought. Further information can be obtained from the Secretary, Imperial Agricultural Bureaux, 2 Queen Anne's Gate Buildings, London, S.W.1, and applications made by May 1 .

\section{Bicentenary of Nicolas Leblanc}

Among the world's benefactors whose discoveries have been ill-requited by their fellows was the French surgeon and chemist, Nicolas Leblanc, who was born at Ivry-de-Pré in the Département of Cher on Decem. ber 6,1742 . Though of poor middle-class parents, he was able to study medicine at the College de France and ultimately became surgeon to the unfortunate Louis-Philippe-Joseph, Duke of Orleans. In 1775 the Paris Academy of Sciences offered a prize of 2,400 livres for a practical process of producing soda from common salt. By 1787 Leblanc had solved the problem, and through the generosity of the Duke was enabled, with Dizé, to erect a factory at St. Denis, and in 1791 a patent was granted him. In 
1793, however, the Duke fell beneath the guillotine, and the factory was confiscated. Though in later years the factory was restored to Leblanc, together with a small monetary recompense, it was all in vain. Leblanc struggled hard against his misfortunes, but at the age of sixty-three his mind gave way and on January 16, 1806, he committed suicide. His process, however, gradually came into use and in 1883 Dumas, speaking to the Paris Academy of Sciences, said that the annual consumption of carbonate of soda in Europe and America, produced by Leblanc's process, was then estimated at between $700,000,000$ and $800,000,000 \mathrm{kgm}$. In spite of this, little was known of the discoverer. Four years after Dumas spoke, a bronze statue of Leblanc was erected in the forecourt of the Conservatoire des Arts et Métiers in Paris.

\section{Simplified Electrically Heated Hotbeds}

A RePort. Ref. W/T7, by C. A. Cameron Brown and E. W. Golding, issued by the British Electrical and Allied Industries Research Association, describes experiments carried out to determine whether a simple method of heating hotbeds electrically can be applied successfully to the intensive production of early salad crops in small frames such as are used by non-professional growers. The method consists essentially in equipping a frame with a soil-heating cable or with a transformer-fed bare iron wire to give a loading of 2-5 watts per sq. ft. Heating is controlled, from a convenient point in the domestic premises from which supply is taken, to give certain regular 'doses' of heat in each 24-hour period. These doses vary from 40 to $\mathbf{4 5}$ watt-hours per sq. ft. per day, depending on the district. The two most convenient modes of procedure appear to be either with a loading suitable for all-night running or with a lower loading suitable for continuous running. The method is designed for operation on the domestic two-part tariff and to take advantage of the low running charges available. The experiments have shown that the method is a practical and economical way of producing lettuces of first-class quality from mid-March onwards, with little attention and at a total cost, including overhead charges, well below the current retail prices in shops. While early lettuce is the main crop, other crops can be raised, either simultaneously, such as carrots, or in succession, thus adding to the value obtainable from the hotbed installation.

\section{Tuberculosis in the United States}

According to the Journal of the American Medical Association of September 26, the United States National Tuberculosis Association has reported that 44 persons per 100,000 of population died of tuberculosis in 1941, as compared with 46 in 1940 . In 1941 the deaths from tuberculosis in the United States amounted to 59,173 , and 105,714 fresh cases were reported. The highest tuberculosis death-rate occurred in Arizona (171 per 100,000). Other high rates per 100,000 reported were in the District of Columbia (82), Tennessee (79), Maryland (74), Kentucky (67) and New Mexico (65). The lowest death-rate reported was from Utah (11). Other States with a rate far below the national average were Wyoming (13), Iowa (15), Nebraska (15), Idaho (16), North Dakota (18), New Hampshire (21) and Kansas (22). New York State reported 6,208 deaths $-a$ rate of $45 \cdot 5$.

\section{New Zealand Earthquakes}

DURING August 1942, ten strong earthquakes were registered by the seismographs at Wellington, Auckland, Christchurch, Arapuni, New Plymouth and Tuai in New Zealand (Prov. Bull. No. P.126, New Zealand Seismological Report; Dominion Observatory, Wellington, N.Z., 1942, August). The earthquake on August 1 was a local shock, namely, the Wairarapa Earthquake, and that on August 29 had an estimated depth of focus near $600 \mathrm{~km}$. Altogether there were twenty-three local shocks felt in New Zealand during the month, of which by far the strongest was that on August 1 at about $12 \mathrm{~h}$. $34 \cdot \mathrm{lm}$. U.T. with epicentre near lat. $41 \cdot 0^{\circ} \mathrm{S}$., long. $175 \cdot 8^{\circ} \mathrm{E}$. This was felt from near Auckland to Dunedin and Queenstown, and in parts of Wairarapa had an intensity of rather more than 8 on the Rossi-Forel scale.

\section{History of Science}

Is Catalogue 70, Messrs. E. F. Goldsmith and Co., of 45 Old Bond Street, London, W.1, are offering for sale the library of Prof. A. Wolf, formerly professor of the history and philosophy of science at University College, London, and some new acquisitions, amounting in all to 834 items. The catalogue includes works on anthropology, astronomy, biography, biology, botany, chemistry, mathematics, optics, philosophy, psychology and statistics. Among the outstanding volumes are the first edition of "Astronomici Veteres" (1499), Tycho Brahe's "Epistolæ Astronomicæ" (1595), Simon Stevin's "Euvres Mathématiques" (1634), Scheele's "Chemical Essays" and Volta's "Collezione dell' Opere" (1816). Modern writers are represented by numerous works of Einstein (including his "Brief Outline of the Development of the Theory of Relativity" from the special issue of NATURE on Relativity published on February 17, 1921), Freud, Galton, Karl Pearson and J. J. Thomson.

\section{Announcements}

Mr. Orville Wright, of Dayton, Ohio, has been elected an honorary member of the Institution of Mechanical Engineers in recognition of his distinguished contributions to mechanical science. Through many years of patient and productive experiment Mr. Orville Wright, with his late brother Wilbur Wright, developed an aeroplane, with wing sections, motor, and controls, which made possible the flight of Orville Wright in 1903.

Prof. G. P. Thomson, professor of physics in the Imperial College of Science and Technology, is to deliver the May Lecture for 1943 of the Institute of Metals. His subject will be "Electron Diffraction". It is of interest to recall that his father, the late Sir J. J. Thomson, delivered the Institute's May Lecture in 1915, speaking on "The Conduction of Electricity through Metals".

The Faculty of Science of Marx House, London, organized a symposium on "Science and Technology in the Soviet Union" which was held during April 5 and 6 last (see NATURE, April 18, p. 426, and May 16, p. 545). Articles based on papers presented at these meetings by Prof. J. D. Bernal, Mr. H. P. Vowles, Dr. N. F. M. Henry, Mr. H. Rose, Dr. M. Ruhemann and Mr. J. L. Fyfe have now been brought together in a pamphlet, obtainable from the Organizing Secretary, Marx House, 1 Doughty Street, London, W.C.1, price $2 s$. 